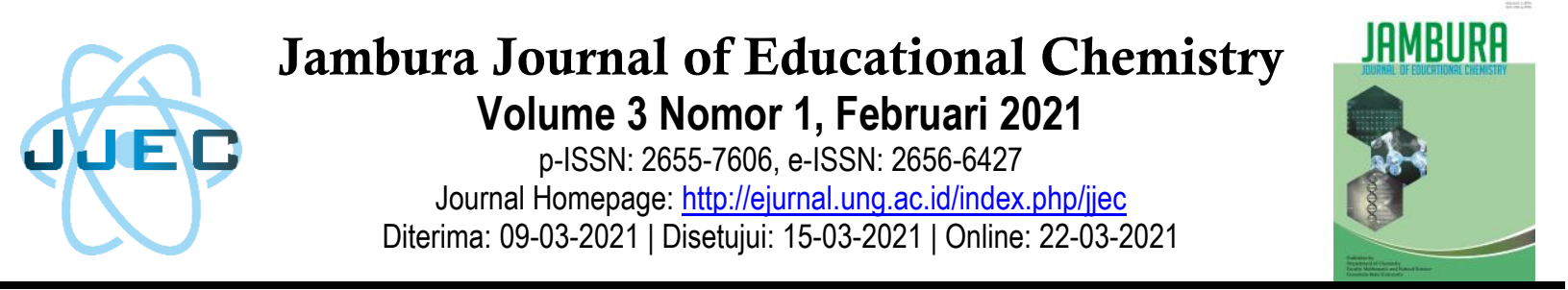

\title{
Identifikasi Miskonsepsi Menggunakan Tes Pilihan Ganda dengan CRI Termodifikasi Materi Larutan Elektrolit dan Non Elektrolit
}

\author{
Meiske Hasan¹, Astin Lukum², Erni Mohamad³ \\ Prodi Pendidikan Kimia, Jurusan Kimia, Fakultas MIPA, Universitas Negeri Gorontalo \\ Jl. Prof. Dr. Ing. B. J. Habibie, Moutong, Tilongkabila, Kabupaten Bone Bolango, Gorontalo, \\ Indonesia \\ e-mail: meiskehasan0@gmail.com
}

\begin{abstract}
Abstrak
Penelitian ini bertujuan untuk mengetahui miskonsepsi siswa MAN 1 Kota Gorontalo tentang konsep larutan elektrolit dan non elektrolit dengan menggunakan Tes Pilihan Ganda dengan CRI Termodifikasi. Jenis Penelitian ini adalah deskriptif dengan pendekatan kualitatif. Subyek penelitian ini adalah siswa kelas X MAN 1 Kota Gorontalo sebanyak 225 orang. Instrumen berupa soal pilihan ganda beralasan terbuka menggunakan CRI Termodifikasi dengan 25 soal pilihan ganda. Data penelitian diperoleh dari hasil tes pilihan ganda beralasan terbuka. Hasil Penelitian menunjukan bahwa menggunakan Tes Pilihan Ganda Dengan CRI Termodifikasi diketahui siswa Kelas X MAN 1 Kota Gorontalo mengalami Miskonsepsi dengan Persentase tertinggi pada indikator menjelaskan penyebab kemampuan larutan elektrolit yakni Miskonsepsi 1 sebesar 25\%, Miskonsepsi 2 sebesar 18\% dan Miskonsepsi 3 sebesar 12\%. Indikator dengan nilai persentase terendah adalah Indikator pengertian larutan elektrolit dan non elektrolit yakni Miskonsepsi 1 sebesar 15\%, Miskonsepsi 2 sebesar 10\% dan Miskonsepsi 3 sebesar 6\%.
\end{abstract}

Kata kunci: Miskonsepsi, CRI Termodifikasi.

\section{PENDAHULUAN}

Kimia merupakan salah satu ilmu pengetahuan alam yang erat kaitannya dengan kehidupan. Konsep kimia secara umum bersifat abstrak, penyederhanaan dari keadaan sesungguhnya, dan bersifat berhubungan. Konsep yang abstrak mengakibatkan banyak peserta didik mengalami kesulitan dalam memahami dan menerapkannya dalam kehidupan sehari-hari. Hal ini terjadi karena proses pembelajaran kimia kurang dikaitkan dengan kehidupan sehari-hari yang mengakibatkan pembelajaran tersebut menjadi kurang bermakna. Selain itu peserta didik merasa bahwa konsep kimia hanya sedikit memberikan kebermanfaatan (Budhi, 2018). Tujuan pembelajaran kimia adalah mewujudkan peserta didik yang menguasai konsep-konsep kimia dan menerapkan dalam memecahkan masalah dalam kehidupan sehari-hari (Depdiknas, 2007).

Salah satu ilmu yang dipandang siswa sebagai ilmu yang sulit dipahami. Kesulitan dalam memahami kimia ini dipengaruhi oleh karakteristik dari ilmu kimia itu sendiri, dimana sebagian besar ilmu kimia bersifat abstrak dan kompleks (Lukum \& Botutihe, 2018).

Menurut Fitria (2014) Mata pelajaran kimia merupakan salah satu cabang ilmu pengetahuan alam yang berkaitan dengan konsep yang harus dipahami serta memberikan inovasi agar peserta didik dapat memecahkan masalah dan mencari solusi yang akan menghasilkan pengetahuan,pengalaman dan makna serta menerapkan dalam kehidupan sehari-hari oleh 
peserta didik. Penerapan ilmu pengetahuan kimia di awali dengan pemahaman konsep, prinsip, hukum dan teori kimia yang benar. Memahami konsep merupakan hal yang paling penting, terkait dengan konsep jika peserta didik memahami konsep yang salah maka disebut sebagai Miskonsepsi.

Menurut Adu-Gyamfi \& Ampiah (2019) bahwa Miskonsepsi merupakan konsep yang dibangun oleh peserta didik yang ciptakan oleh peserta didik itu sendiri dengan berdasarkan dengan apa yang mereka lihat dengan indera mereka dan masuk akal merupakan sumber Miskonsepsi, Menurut Sadhu (2019) bahwa miskonsepsi merupakan konsep yang diakibatkan ketika peserta didik dalam hal proses pembelajaran dalam mengolah informasi kedalam system kognitif jika yang diterima adalah informasi yang sesuai dengan konsep yang ada dan otomatis informasi tersebut akan langsung menambah pengetahuan. Begitupun sebaliknya, maka proses ini dinamakan sebagai proses asimilasi.

Berdasarkan Penelitian yang dilakukan oleh Putri (2018) Bahwa pada materi larutan elektrolit dan non elektrolit siswa mengalami Miskonsepsi termasuk kedalam kategori sedang dengan persentase 54\%, Miskonsepsi siswa dengan kategori sangat tinggi terjadi pada tiga indikator soal yaitu menentukan larutan berdasarkan daya hantarnya sebesar $85 \%$, menentukan senyawa elektrolit dan sifat ikatannya sebesar $82 \%$, dan menentukan larutan elektrolit yang bersifat kovalen polar sebesar $82 \%$.

Materi dalam kimia yang salah satunya menimbulkan miskonsepsi yaitu larutan elektrolit dan non elektrolit. Materi ini lebih menitikberatkan pada pemahaman secara representatif dalam tiga tingkat yang berbeda yaitu makroskopik, submikroskopik dan simbolik. Sehingga untuk mengatasi terjadinya miskonsepsi pada peserta didik perlunya pemahaman konsep secara keseluruhan.

Salah satu cara yang digunakan untuk mengetahui seberapa besar peserta didik mengalami miskonsepsi yaitu dengan menggunakan metode Certainty of Response Index (CRI) Termodifikasi. Kelebihan dari metode CRI ini dapat menggambarkan tingkat pemahaman siswa terhadap suatu konsep dan mengetahui tingkat keyakinan dalam menjawab tes atau soal.

Tujuan penelitian ini yaitu untuk mengetahui Miskonsepsi Siswa MAN 1 Kota Gorontalo Tentang Konsep Larutan Elektrolit Dan Non Elektrolit Dengan Menggunakan Tes Pilihan GandaDengan CRI Termodifikasi”

\section{METODE PENELITIAN Jenis Penelitian}

Jenis Penelitian yang digunakan dalam penelitian ini adalah deskriptif kualitatif. Menurut Sugiyono (2017) bahwa penelitian kualitatif adalah metode penelitian yang bedasarkan pada filsafat postpositivisme yang digunakan untuk meneliti pada kondisi obyek yang alamiah.

\section{Waktu dan Tempat Penelitian}

Penelitian Ini dilaksanakan di MAN 1 Kota Gorontalo yang bertempat di Jalan Poigar No.26 Kelurahan Molosifat Kecamatan Sipatana, Kota Gorontalo, Provinsi Gorontalo. Sekolah tersebut merupakan Lokasi yang dipilih peneliti dalam melakukan penelitian karena sekolah tersebut salah satu sekolah unggulan yang ada di Kota Gorontalo.

\section{Subjek Penelitian}

Sumber data dalam penelitian ini adalah peserta didik kelas X MAN 1 Kota Gorontalo tahun ajaran 2019/2020. Teknik pengambilan sampel yang digunakan pada penelitian ini adalah purposive sampling (sampel bertujuan). Menurut Suharsimi (2009) bahwa Purposive sampling adalah teknik pengambilan sampel yang dilakukan dengan cara mengambil subyek bukan didasarkan strata, random atau daerah.

\section{Prosedur Penelitian}

Tahapan yang dilaksanakan dalam penelitian ini adalah

1) Melakukan Observasi

2) Melakukan pengumpulan data melalui tes pilihan ganda dengan CRI Termodifikasi 
3) Mengidentifikasi jawaban siswa dengan mengacu pada instrumen CRI termodifikasi disertai analisis.

\section{Teknik Pengumpulan Data}

Teknik pengumpulan data dalam penelitian ini adalah menggunakan dua metode yakni CRI Termodifikasi dan Tes Pilihan ganda sebagai berikut.

\section{a. CRI Termodifikasi}

Instrumen CRI termodifikasi merupakan instrumen yang menambah tingkat keyakinan ataupun kepastian responden dalam menjawab setiap pertanyaan yang akan diberikan. Oleh karena itu peneliti menggunakan CRI termodifikasi dapat menganalisis lebih dalam adanya Miskonsepsi pada materi yang akan diteliti.

\section{b. Tes Pilihan Ganda}

Tes yang akan digunakan pada penelitian ini sebanyak 25 butir soal yang terdiri atas 3 indikator soal. Setiap butir soal terdiri dari tiga tingkatan. Tingkat pertama atau Q1 berupa soal pilihan ganda yang memiliki lima pilihan jawaban yang telah ditentukan yang dapat mengukur tentang pemahaman konsep larutan elektrolit dan non-elektrolit. Tingkat kedua atau Q2 merupakan pertanyaan alasan peserta didik berupa pemberian alasan terbuka yang dapat mendukung jawaban Q1. Tingkat ketiga atau Q3 merupakan pertanyaan tingkat keyakinan peserta didik dalam memilih jawaban dan alasan yang terdiri dari enam pilihan keyakinan yang telah ditentukan terhadap Q1 dan Q2.

\section{Teknik Analisis Data}

Adapun pada penelitian ini menggunakan metode analisis CRI termodfikasi analisis deskriptif kualitatif dengan tujuan untuk memberikan deskripsi hasil penelitian yang terkait dengan Miskonsepsi peserta didik.

\section{HASIL DAN PEMBAHASAN Deskripsi Hasil Penelitian}

Penelitian ini merupakan penelitian deskriptif kualitatif yang bertujuan untuk mengetahui Miskonsepsi Siswa MAN 1 Kota Gorontalo Tentang Konsep Larutan Elektrolit Dan
Non Elektrolit Dengan Menggunakan Tes Pilihan GandaDengan CRI Termodifikasi. Total sampel pada penelitian ini sebanyak 225 responden yang tersebar pada 7 kelas. Adapun Analisis Miskonsepsi menggunakan Instrumen Three-tier diagnostic test sebagai data pendukung dalam analisis miskonsepsi menggunakan Tes Pilihan Ganda dengan CRI Termodifikasi.

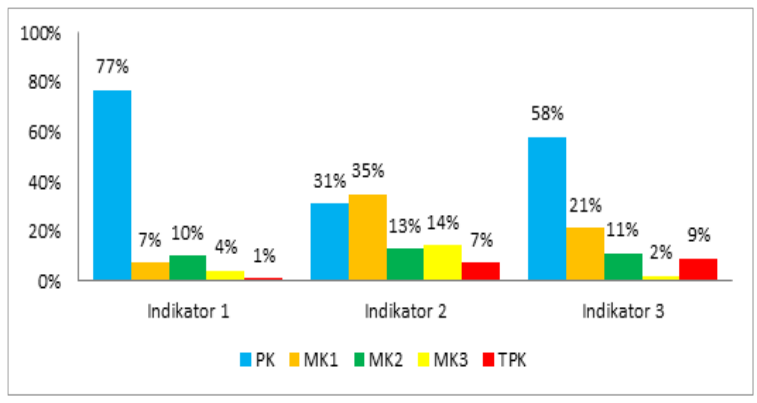

Gambar 1. Presentasi Konsepsi siswa Kelas X IPA I Untuk Setiap Indikator

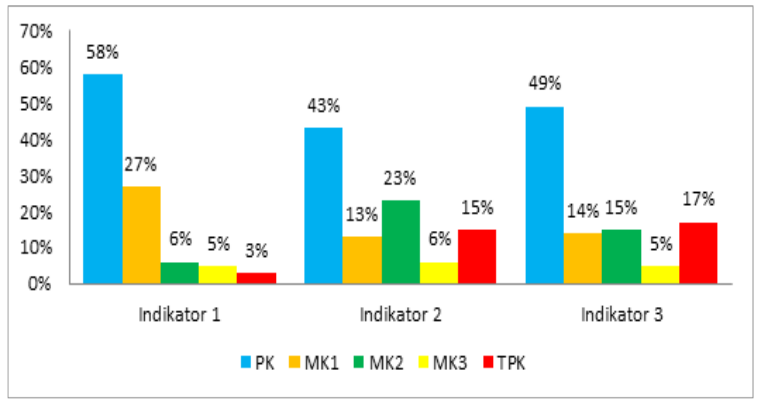

Gambar 2. Presentasi Konsepsi siswa Kelas X IPA II Untuk Setiap Indikator

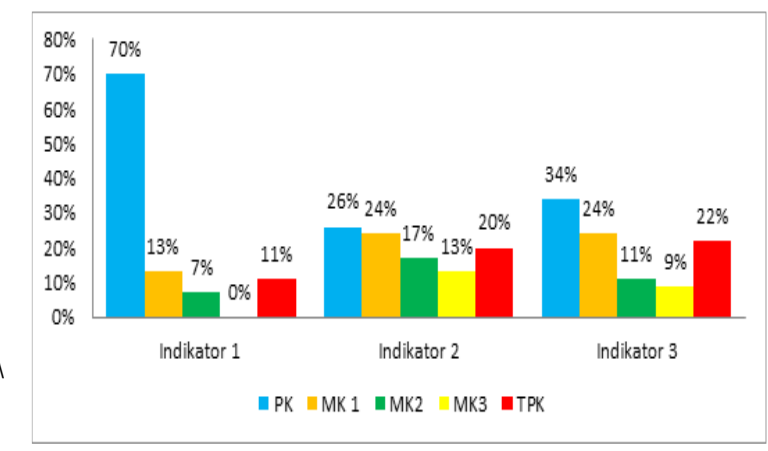

Gambar 3. Presentasi Konsepsi siswa Kelas X IPA III Untuk Setiap Indikator 


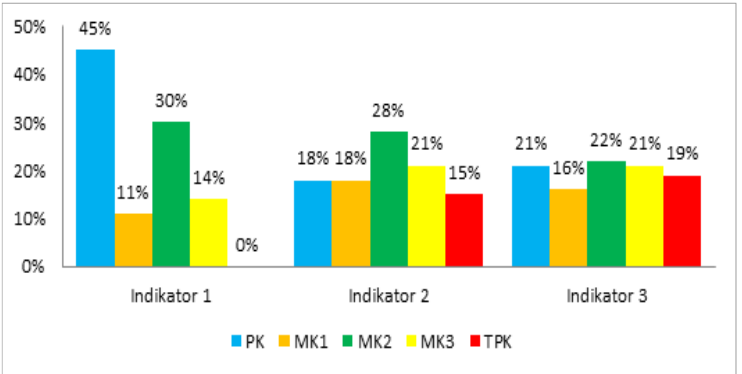

Gambar 4. Presentasi Konsepsi siswa Kelas X IPA IV Untuk Setiap Indikator

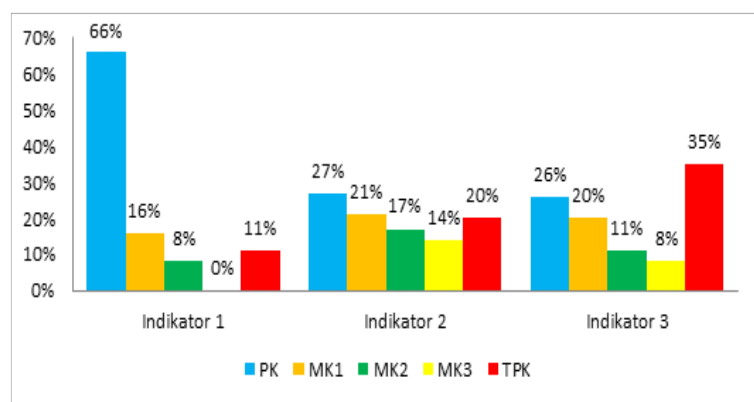

Gambar 5. Presentasi Konsepsi siswa Kelas X IPA V Untuk Setiap Indikator

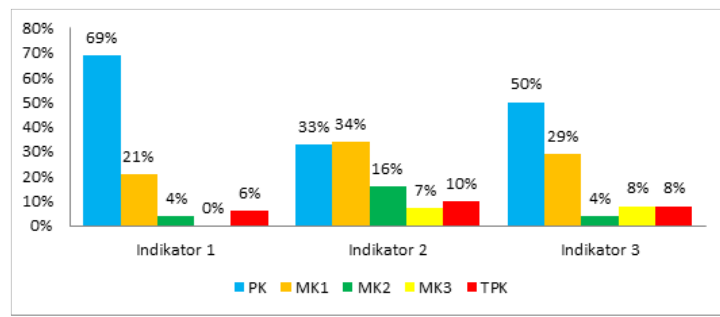

Gambar 6. Presentasi Konsepsi siswa Kelas X Excellent 1 Untuk Setiap Indikator

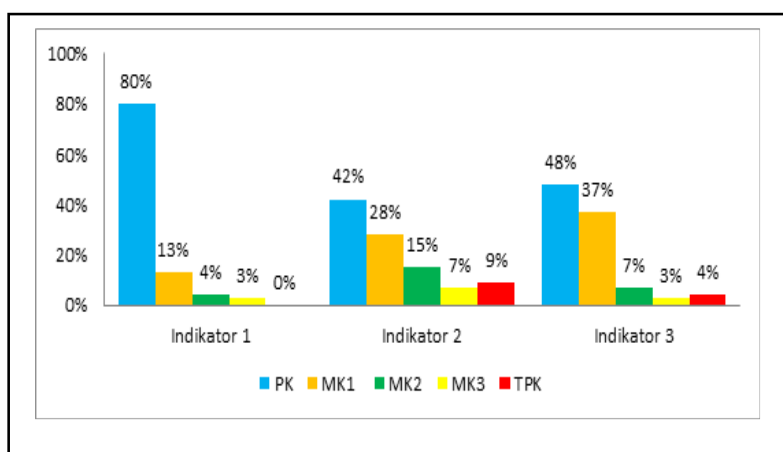

Gambar 7. Presentasi Konsepsi siswa Kelas X Excellent 2 Untuk Setiap Indikator

\section{Pembahasan}

a. Miskonsepsi pada Indikator Pemahaman tentang pengertian larutan elektrolit dan non elektrolit

Pada indikator ini dapat disimpulkan bahwa secara keseluruhan siswa kelas $\mathrm{X}$ yang termasuk kategori Paham konsep dengan persentase tertinggi terdapat pada Kelas $\mathrm{X}$ Excellent II yakni sebesar $80 \%$ sedangkan persentase terendah terdapat pada Kelas X IPA IV yakni hanyalah 45\%. Pada kategori Miskonsepsi 1 persentase tertinggi pada Kelas X IPA II yakni sebesar $27 \%$ sedangkan persentase terendah pada Kelas X IPA I yakni hanyalah 7\%. Pada kategori Miskonsepsi 2 dengan persentase tertinggi terdapat pada Kelas X IV yakni sebesar 30\% sedangkan persentase terendah terdapat pada Kelas $\mathrm{X}$ Excellent I dan II yang merupakan Kelas dengan rata-rata pemahaman konsep yang cukup tinggi. Pada kategori Miskonsepsi 3 dengan persentase terendah terdapat pada kelas X IPA IV yakni sebesar $14 \%$ sedangkan persentase terendah terdapat pada Kelas X IPA IV, X Excellent I dan II yakni hanyalah $0 \%$ yang artinya Tidak mengalami miskonsepsi paling parah. Pada kategori tidak paham konsep persentase terendah terdapat pada Kelas X IPA III dan X IPA V yakni sebesar 11\% sedangkan Persentase terendah terdapat pada $\mathrm{X}$ IPA IV dan X Excellent II yakni $0 \%$.

\section{b. Miskonsepsi Indikator Pemahaman tentang penyebab kemampuan larutan elektrolit}

Pada Indikator Kedua yakni pemahaman tentang menjelaskan penyebab kemampuan larutan elektrolit, Dapat disimpulkan dari seluruh siswa bahwa ; (a) Siswa yang memahami konsep dengan presentasi tertinggi pada kelas X IPA II yakni sebesar $43 \%$ sedangkan persentase terendah terdapat pada X IPA IV yakni sebesar 18\%. (b) Siswa yang mengalami Miskonsepsi 1 dengan persentase tertinggi terdapat pada kelas X IPA I yakni sebesar 35\% sedangkan persentase terendah Terdapat pada X IPA II yakni $13 \%$. (c) Siswa yang mengalami Miskonsepsi 2 dengan persentase tertinggi terdapat pada Kelas X IPA IV yakni sebesar $28 \%$ sedangkan persentase terendah terdapat pada Kelas X IPA I yakni sebesar $13 \%$. 
(d) Siswa yang mengalami Miskonsepsi 3 dengan persentase tertinggi pada Kelas X IPA IV yakni sebesar $21 \%$ sedangkan persentase terendah terdapat pada Kelas X IPA II. (e) Siswa yang tidak paham konsep dengan persentase tertinggi pada Kelas X IPA III dan X IPA V yakni sebesar 20\% sedangkan persentase terendah terdapat pada $\mathrm{X}$ IPA I yakni sebesar 7\%.

\section{c. Miskonsepsi pada Indikator Pemahaman tentang Mengelompokkan larutan kedalam larutan elektrolit dan non-ektrolit berdasarkan sifat hantaran listriknya}

Pada Indikator ketiga pemahaman tentang mengelompokkan larutan kedalam larutan elektrolit dan non-ektrolit berdasarkan sifat hantaran listriknya, (a) siswa yang memahami konsep dengan persentase tertinggi terdapat pada Kelas X IPA I yakni sebesar 58\% sedangkan persentase terendah terdapat pada Kelas X IPA IV dengan persentase terendah yakni sebesar $21 \%$. (b) siswa yang mengalami Miskonsepsi 1 dengan persentase tertinggi terdapat pada kelas $\mathrm{X}$ Excellent II yakni sebesar $37 \%$ sedangkan persentase terendah terdapat pada Kelas X IPA II yakni sebesar $14 \%$. (c) Siswa yang mengalami Miskonsepsi 2 dengan persentase Tertinggi terdapat pada Kelas X IPA IV yakni sebesar 22\%, sedangkan persentase terendah terdapat pada kelas X Excellent I yakni sebesar 4\%. (d) Siswa yang mengalami Miskonsepsi 3 dengan presentasi tertinggi terdapat pada Kelas X IPA 4 yakni sebesar $21 \%$, sedangkan untuk persentase terendah terdapat pada Kelas X IPA I yakni sebesar 2\%. (e) Siswa yang tidak paham konsep dengan pesentase tertinggi terdapat pada kelas X IPA $\mathrm{V}$ yakni sebesar $35 \%$ sedangkan persentase terendah terdapat pada Kelas X Excellent I yakni sebesar $4 \%$.

\section{KESIMPULAN}

Penggunaan Tes Pilihan Ganda dengan CRI Termodifikasi diketahui siswa Kelas X MAN 1 Kota Gorontalo mengalami Miskonsepsi dengan Persentase tertinggi pada indikator menjelaskan penyebab kemampuan larutan elektrolit yakni Miskonsepsi 1 sebesar 25\%, Miskonsepsi 2 sebesar
18\% dan Miskonsepsi 3 sebesar 12\%. Indikator dengan nilai persentase terendah adalah Indikator pengertian larutan elektrolit dan non elektrolit yakni Miskonsepsi 1 sebesar 15\%, Miskonsepsi 2 sebesar 10\% dan Miskonsepsi 3 sebesar 6\%.

\section{UCAPAN TERIMA KASIH}

Terima Kasih saya sampaikan kepada Ibu Prof. Dr. Astin Lukum, M.Si selaku Pembimbing I dan Ibu Erni Mohamad, S.Pd, M.Si selaku Pembimbing II yang telah meluangkan waktu membimbing dan membantu serta memberikan arahan kepada penulis hingga selesai skripsi ini. Teriring Doa semoga Allah SWT membalas dengan kebaikan yang lebih.

\section{DAFTAR PUSTAKA}

Adu-Gyamfi, K., \& Ampiah, J. G. (2019). Students' Alternative Conceptions Associated With Application of Redox Reactions in Everyday Life. In Asian Education Studies (Vol. 4, Issue 1, p. 29). July Press Pte. Ltd. https://doi.org/10.20849/aes.v4i1.590

Budhi, H. S. (2018). Model Pembelajaran Berbasis Pengalaman untuk Meminimalkan Miskonsepsi Siswa pada Materi Cahaya. THABIEA: JOURNAL OF NATURAL SCIENCE

https://journal.iainkudus.ac.id/index.php/Tha biea/article/view/4110

Depdiknas, P. K. B. (2007). Model Penilaian Kelas Kurikulum Berbasis Kompetensi. Diakses pada tanggal 9 Maret 2021.

Fitria, A. (2014). Miskonsepsi mahasiswa dalam menentukan grup pada struktur aljabar menggunakan certainty of response index (CRI) di jurusan pendidikan matematika IAIN $\quad$... $\quad$ core.ac.uk. https://core.ac.uk/download/pdf/327227535. pdf

Lukum, A., \& Botutihe, D. N. (2018). Studi Komparasi Kemampuan Pemahaman Konseptual, Algoritmik, dan Grafis Mahasiswa Jurusan Kimia pada Materi Asam Basa. Jambura Journal of Educational Chemistry. https://www.neliti.com/publications/277401/ studi-komparasi-kemampuan-pemahaman- 
konseptual-algoritmik-dan-grafismahasiswa-j

Putri, L. (2018). Identifikasi Miskonsepsi Siswa pada Materi Larutan Elektrolit dan Nonelektrolit di SMA Negeri 4 Banda Aceh. repository.ar-raniry.ac.id.

https://repository.arraniry.ac.id/id/eprint/5308/

Sadhu, S. (2019). Uncover Student's Alternative Conception in Acid-Base Theory Using a Modified Certainty of Response Index
Instrumen. Formatif: Jurnal Ilmiah Pendidikan MIPA, 9(1).

Sugiyono, P. D. (2017). Metode Penelitian Bisnis: Pendekatan Kuantitatif, Kualitatif, Kombinasi, dan R\&D. Penerbit $C V$. https://scholar.google.com/citations?view_o $\mathrm{p}=$ view_citation\&hl=en\&user $=\mathrm{uUIIujUAA}$ AAJ\&pagesize $=100 \&$ citation_for_view $=u U$ IIujUAAAAJ:M3NEmzRMIkIC

Suharsimi, A. (2009). Dasar-dasar evaluasi pendidikan. Jakarta: Bumi Aksara. 